\title{
UJI ALKOHOL PADA FERMENTASI TUAK
}

\author{
St. Aisyah S. ${ }^{1^{*}}$, Hasyimuddin ${ }^{1}$, Samsinar $^{1}$ \\ ${ }^{1}$ Jurusan Biologi Fakultas Sains dan Teknologi \\ Universitas Islam Negeri (UIN) Alauddin Makassar \\ *E-mail : aisyahsijid@gmail.com
}

\begin{abstract}
Abstrak: Tuak merupakan suatu jenis cairan/minuman yang mengandung alkohol yang terbuat dari nira kelapa atau jenis pohon penghasil nira lainnya seperti siwalan dan lontar yang disadap. Cairan ini dapat dijadikan sebagai bahan utama pembuatan gula merah. Dalam keadaan segar, nira mempunyai rasa manis, aroma yang khas, berbau harum dan relatif tidak berwarna. Selain bahan baku pembuatan gula, nira dapat pula digunakan sebagai bahan makanan lain yaitu minuman keras (tuak), asam cuka dan minuman segar. Dalam proses penyadapan nira ini perlu penanganan, baik sebelum maupun sesudah penyadapan. Hal ini karena nira merupakan cairan yang mengandung kadar gula tertentu, yaitu sukrosa, glukosa, fruktosa serta karbohidrat yang memiliki derajat keasaman rata-rata 6-7. Bila nira disimpan maka akan terjadi fermentasi oleh adanya mikroorganisme yang terdapat dalam nira sehingga menyebabkan rasa asam karena terbentuknya asam asetat. Dari beberapa referensi terkait mengenai pengaruh pemberian tuak terhadap mencit sehingga dikaitkan bahwa pemberian tuak dengan jangka waktu yang lebih lama dapat menurunkan motilitas spermatozoid pada mencit.
\end{abstract}

Kata Kunci: Tuak, Alkohol

\section{PENDAHULUAN}

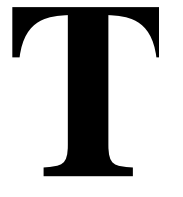

uak merupakan suatu jenis cairan/minuman yang mengandung alkohol yang terbuat dari nira kelapa atau jenis pohon penghasil nira lainnya seperti siwalan, lontar dan aren yang disadap dan kemudian hasil sadapannya didiamkan selama beberapa hari. Pemberian tuak pada mencit dengan dosis yang lebih tinggi atau berlebihan dan waktu yang cenderung lebih lama dapat mempengaruhi atau merusak fungsi organ vital yang terdapat dalam tubuh, contohnya mempengaruhi organ hati, ginjal, otak, jantung dan organ vital lainnya dalam hal ini organ reproduksi. Disamping itu, mengonsumsi minuman beralkohol dapat menyebabkan ketagihan, mabuk dan tidak mampu megendalikan 
diri jika mengkonsumsi dalam jumlah yang berlebihan. Nira aren yang merupakan bahan dasar pembuatan tuak mengandung alkohol dengan kadar $4 \%$.

Alkohol telah menjadi masalah yang umum di seluruh dunia. Di Inggris sekitar $87 \%$ penduduk mengkonsumsi alkohol pada beberapa tahun terakhir (National Collaborating Centre for Mental Health, 2011). Dilaporkan bahwa terdapat kecenderungan konsumsi alkohol pada anak muda di Indonesia 4,3\% siswa dan 0,8\% siswi paling tidak pernah mengkonsumsi alkohol dalam sebulan terakhir (World Health Organization, 2011).

Alkohol secara kimawi merupakan zat hasil fermentasi dan memiliki jalur metabolisme tersendiri dalam tubuh. Alkohol mempengaruhi beberapa sistem organ ataupun organ dalam tubuh. Sistem organ atau organ yang dipengaruhi antara lain hati, sistem saraf pusat, sistem kardiovaskular, sistem kekebalan tubuh, sistem darah, sistem hormonal, sistem pencernaan, pankreas, ginjal dan keseimbangan elektrolit. Alkohol juga dapat mempengaruhi penyerapan zat gizi, perkembangan janin serta mempengaruhi resiko untuk beberapa jenis kanker. Alkohol merupakan hasil produksi dari fermentasi, dimana mikroorganisme seperti ragi memecah gula-gula sederhana (seperti gula, atau maltosa), menjadi alkohol, karbondioksida, dan air tanpa bantuan oksigen.

Senyawa alkohol mempunyai nama kimia etanol atau etil alkohol. Alkohol mempunyai zat kimia dengan berat molekul kecil, sehingga dapat dengan mudah diserap tubuh. Pemberian alkohol secara berulang-ulang pada kebuntingan dapat merusak plasenta sehingga secara langsung menganggu proses perkembangan embrio (Panjaitan, 2003).

\section{METODE}

Adapun prosedur kerja dalam penelitian ini adalah hasil dari nira yang difermentasikan selama 1 hari sebanyak $1.000 \mathrm{ml}$ yang dimasukkan ke dalam labu alas bulat lalu dialirkan air sebagai pendingin. Labu destilasi yang berisi tuak dipanaskan pada temperatur di bawah $78^{\circ} \mathrm{C}$ dan hasil destilat ditampung pada labu Erlenmeyer. Kemudian dilakukan pengukuran kadar alkohol dengan menggunakan piknometer ukuran $10 \mathrm{ml}$ yang telah dibilas dengan aquadest dan 
dioven selama 15 menit pada suhu $60^{\circ} \mathrm{C}$. Setelah kering piknometer dimasukkan ke dalam desikator selama 5 menit untuk didinginkan lalu piknometer yang kosong ditimbang menggunakan neraca analitik. Setelah itu piknometer diisi dengan aquadest sampai penuh dan piknometer ditimbang kembali kemudian dibilas dengan aquades dan dimasukkan ke dalam oven selama 15 menit pada suhu $60^{\circ} \mathrm{C}$. Setelah kering piknometer dimasukkan ke dalam desikator selama 5 menit dan piknometer yang kosong ditimbang menggunakan neraca analitik. Kemudian piknometer diisi dengan tuak sampai penuh dan ditimbang kembali. Hasil dari penimbangan dihitung dengan menggunakan rumus bobot jenis untuk mengetahui kadar/kandungan alkohol pada tuak.

Bobot jenis $p=\frac{\mathrm{w} 2-\mathrm{w} 0}{\mathrm{w} 1-\mathrm{w} 0} \mathrm{x}$ suhu

\section{HASIL DAN PEMBAHASAN}

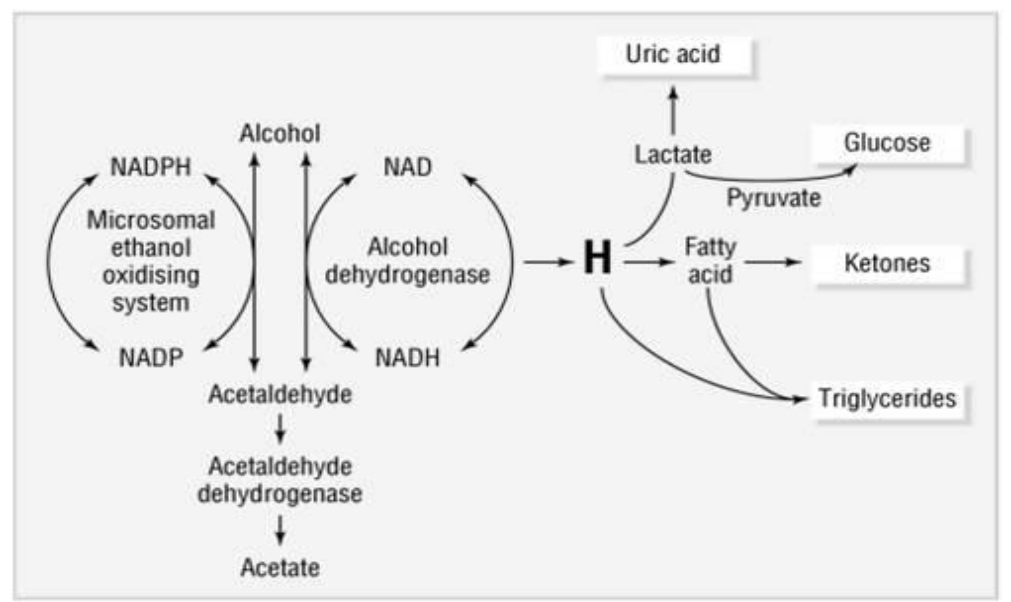

Gambar 1. Reaksi kimia metabolisme etanol (Sumber: Lieberman et al, 2007)

Etanol sebagai zat penting dalam alkohol bersifat mudah larut dalam air dan lemak sehingga etanol langsung diserap ke dalam usus melalui difusi pasif. Ketika alkohol dikonsumsi sekitar 20\% diserap oleh lambung dan $80 \%$ diserap oleh usus halus. Alkohol jika dikonsumsi dalam perut kosong akan mencapai kadar puncak dalam darah setelah 15-90 menit. Penyerapan alkohol menjadi lebih 
lambat dan lebih sedikit bila konsumsi alkohol dilakukan bersamaan dengan makanan (Wardlaw, 2012).

Sekitar 85-98\% etanol yang diserap oleh tubuh di metabolisme dalam hati, sisanya dikeluarkan melalui paru-paru dan ginjal. Enzim yang berperan dalam memetabolisme etanol antara lain enzim alcocohol dehydrogenase, acetaldehyde dehydrogenase, microsomal ethanol oxidizing system (MEOS). Alcocohol dehydrogenase dan MEOS merubah alkohol menjadi asetaldehid, sedangkan acetaldehyde dehydrogenase mengubah asetaldehid menjadi asetat (Lieberman et al, 2007).

Tabel 1. Kandungan alkohol pada tuak

\begin{tabular}{|c|c|}
\hline Lama Fermentasi & Kandungan Alkohol \\
\hline 1 hari & $35 \%$ \\
\hline
\end{tabular}

\section{Efek alkohol terhadap hati}

Alkohol dapat menimbulkan penyakit hati. Jenis penyakit hati yang ditimbulkan oleh penyakit hati. Jenis penyakit hati yang ditimbulkan oleh alkohol, antara lain: fatty liver (perlemakan hati), alcoholic hepatitis dan liver cirrhosis. Timbulnya penyakit hati oleh karena alkohol dapat dijelaskan secara biokimia. Fatty liver (timbunan lemak dalam hati) terjadi disebabkan oleh kombinasi gangguan oksidasi asam lemak dan peningkatan lipogenesis oleh karena perubahan potensial redoks $\mathrm{NADH} / \mathrm{NAD}^{+}$dalam hati serta gangguan terhadap aktivitas faktor transkripsi yang mengatur ekspresi enzim yang terlibat. Adapun mekanisme terjadinya fibrosis hati antara lain disebabkan oleh: (1) Konsumsi alkohol menyebabkan perusakan sel hati sehingga terjadi pelepasan berbagai mediator untuk induksi atau aktivasi stellate cells, (2) Asetaldehid secara langsung meningkatkan eksresi kolagen pada stellate cells, (3) konsumsi alkohol meningkatkan kadar LPS dalam hati. LPS dapat secara langsung meningkatkan aktivasi stellate cells melalui peningkatan sinyal TGF- $\beta$ dan secara tidak langsung melalui aktivasi sel Kuppfer untuk melepaskan sitokin probiotik, (4) Sel NK teraktivasi pada hepatitis virus atau terapi IFN- $\alpha$. Sel NK teraktivasi dapat membunuh stellate cells melalui pelepasan TRAIL dan menghambat proliferasi 
stellate cells melalui pelepasan IFN-yang sehingga efek ini berakhir pada penghambatan fibrosis hati (Dasgupta, 2011).

\section{Efek alkohol terhadap ginjal}

Alkohol menyebabkan pembesaran organ ginjal hanya jika telah terjadi sirosis pada hati. Sifat alkohol sebagai diuretik dapat mempengaruhi keseimbangan elektrolit tersebut dapat tergantung dari jumlah dan konsumsi alkohol. Alkohol dapat menyebabkan hipofosfatemia, hipokalsemia, ataupun hipomagnesemia oleh karena peningkatan ekskresi fosfat, kalsium atau magnesium dalam urin. Peningkatan ekskresi kalsium berdampak pada kemungkinan terjadinya osteoporosis. Lebih lanjut ditemukan bahwa osteoporosis lebih mudah terjadi pada peminum alkohol yang mengalami sirosis hati (DiezRuiz et al, 2010).

Alkohol bersifat diuretik alami. Alkohol menekan produksi ADH (Anti Diuretik Hormone atau vasopressin) oleh kelenjar hipofisis di otak. Ketika sekresi ADH ditekan, terjadi peningkatan kehilangan air melalui saluran kencing. Cukup dengan satu teguk dapat menimbulkan respon diuretik (Dasgupta, 2011).

\section{Efek alkohol terhadap sistem kekebalan tubuh}

Alkohol mempengaruhi sistem kekebalan tubuh melalui pengubahan produksi molekul yang berfungsi sebagai sinyal (yaitu sitokin) untuk koordinasi pertahanan tubuh. Akibat yang ditimbulkan dari efek tersebut adalah rentannya daya tahan tubuh terhadap serangan infeksi bakteri, misalnya tuberkulosis atau pneumonia.

Efek modulasi alkohol terhadap pertahanan tubuh terjadi tidak hanya melalui konsumsi alkohol kirosis tapi juga melalui konsumsi alkohol akut ataupun melalui konsumsi alkohol sedang. Konsumsi alkohol baik akut maupun kronis menurunkan daya sel fagosit untuk mencerna dan menghancurkan bakteri patogen. Konsumsi alkohol kronis meningkatkan produksi sitokin sehingga terjadi peradangan berlebihan dalam tubuh, sedangkan konsumsi alkohol akut dapat menurunkan produksi sitokin sehingga daya tahan tubuh menurun (National Institute for Alkohol Abuse and Alcoholism, 1997). 


\section{Efek alkohol terhadap sistem darah}

Alkohol mempengaruhi sistem darah serta menyebabkan abnormalitas sel pembentuk darah. Abnormalitas sel darah baik produksi maupun fungsi terjadi pada sel darah merah (eritrosit), sel darah putih (leukosit) dan keping darah (platelet). Gangguan fungsi pada eritrosit dapat menyebabkan anemia. Timbulnya anemia selain disebabkan oleh gangguan fungsi eritrosit juga oleh diferensiasi zat besi. Gangguan pada leukosit dapat menyebabkan kerentanan terhadap infeksi. Gangguan pada platelet dapat menyebabkan gangguan pada pembekuan darah (National Institute for Alcohol Abuse and alcoholism, 1997).

\section{Efek alkohol terhadap sistem hormonal}

Beberapa sistem hormon dapat dipengaruhi antara lain: sistem hypotalamus hypopitutary adrenal axi,, prolaktin, maupun hypothalamicpituitary-gonadal- axis. Gangguan pada sistem hypothalamus-hypopituitaryadrenal-axis menyebabkan terjadinya pseudo-Cushing syndrome, suatu keadaan yang timbul dari kelebihan hormon kortisol dalam tubuh. Gangguan sistem hypothalamus-hypopituitary-gonadal axis oleh konsumsi alkohol pada laki-laki menyebabkan turunnya kadar testosteron sehingga terjadi penurunan fungsi seksual. Gangguan sistem hypothalamus-hypopituitary-gonadal axis pada perempuan oleh konsumsi alkohol menyebabkan gangguan siklus menstruasi. Gangguan siklus menstruasi yang terjadi seperti penundaan ovulasi, anovulasi, ataupun pemendekan fase luteal. Gangguan tersebut disebabkan oleh meningkatnya kadar estrogen dalam tubuh oleh konsumsi alkohol. Konsumsi alkohol meningkakan kadar prolaktin yang berakibat impotensi pada laki-laki dan gangguan menstruasi pada wanita (National Institute for Alcohol Abuse and Alcoholism, 1997).

\section{Efek alkohol terhadap pencernaan}

Alkohol dapat melemahkan fungsi otot sfingter yang berada diantara esofagus dan gaster sehingga timbul sensasi dada tersa terbakar. Kerusakan mukosa esofagus oleh alkohol dapat meningkatkan resiko terkena esofagitis dan kanker esofagus. Alkohol meningkatkan sekresi asam lambung namun hanya pada kadar konsumsi rendah. Konsumsi alkohol kronis menyebabkan atrofi mukosa 
lambung pada dan penurunan sekresi cairan lambung sehingga menurunkan kemampuan menghancurkan bakteri patogen dalam makanan. Alkohol mengganggu penyerapan zat gizi dalam usus halus. Alkohol juga menyebabkan cedera pada mukosa usus, meningkatkan permeabilitas mukosa usus sehingga molekul-molekul berukuran besar termasuk racun bakteri terserap ke dalam darah (National Institute for Alkohol Abuse and Alcoholism, 1997).

\section{Efek alkohol terhadap penyerapan zat gizi}

Konsumsi alkohol berlebihan memiliki beberapa efek dengan terjadinya defesiensi vitamin A di negara Amerika Serikat. Konsumsi alkohol kronis berhubungan dengan penurunan kadar retinol dan retini ester dalam hati (Clugston, 2012). Alkohol juga dapat menyebabkan defisiensi vitamin C. Defisiensi vitamin C ditandai oleh antara lain: sariawan, pendarahn guzi, perifollicular hemorrhages, sefusi cairan sendi, antralgia, lemah, depresi dan gangguan penyembuhan luka. Selain vitamin A dan C alkohol juga dapat menyebabkan defisiensi berbagai vitamin B (Kim, 2009).

\section{Efek alkohol terhadap perkembangan janin}

Anak-anak yang pernah terpapar dengan alkohol ketika dalam kandungan dapat mengalami gangguan perkembangan mental. Gangguan ini disebut dengan Fetal Alcohol Spectrum Disorder (FASD). Termasuk FASD diantaranya adalah Fetal Alcohol Syndrome (FAS) yang salah satunya ditandai oleh gambaran muka yang khas. Gangguan organ yang terkena pada FASD antara lain pada aspek intelegensi. Pada aspek ini terjadi gangguan kemampuan intelektual dan keterbelakangan mental. Telah diteliti bahwa pada paparan alkohol berat selama kandungan berdampak pada skor IQ yang kurang. Rata-rata skor IQ didapatkan sebesar 70 pada anak yang terdiagnosis FAS dan sebesar 80 pada anak yang termasuk FASD namun belum cukup untuk didiagnosis sebagai FAS. Adapun efek penurunan IQ tersebut pada konsumsi alkohol ringan dan sedang belum didapatkan hubungan yang pasti mengingat berbagai penelitian memberikan hasil yang berbeda-beda (Maltson et al, 2011). Anak dengan FASD juga diketahui mengalami gangguan dalam beberapa aspek bahasa (Wyper, 2011). 
Selain FASD terdapat pula kelainan lain pada anak yang disebabkan oleh paparan alkohol yang berat sewaktu masih dalam kandungan. Anak yang terpapar alkohol berat dapat berkembang ke arah gangguan mirip Attention-DeficitHyperactive Disorder (ADHD) dengan karakteristik yang membedakan yaitu gangguan dalam menyebutkan (encoding) materi verbal (Crocker, et al, 2011). Konsumsi alkohol berat sewaktu hamil juga dapat meningkatkan resiko bayi lahir dengan celah bibir (oral clett). Peningkatan tersebut berhubungan dengan varian gen alcohol dehydrogenase 1C (ADH1C) yang bertipe metabolisme lambat, namun tidak ditemukan hubungan resiko pada varian gen ADH1C yang bertipe metabolisme cepat (Boyles et el, 2010).

\section{KESIMPULAN}

Uji Alkohol pada tuak yang difermentasikan selama 1 hari mengandung kadar sebesar $35 \%$.

\section{SARAN}

Perlunya dilakukan penelitian lebih lanjut terhadap pengaruh tuak pada organ vital mencit yaitu pada organ ginjal, hati, embrio mencit, beserta gambaran histopatologi pada mencit.

\section{DAFTAR PUSTAKA}

Boyles, A.I., DeRoo, I.A. Lie, R.T., Taylor, J.A., Jugessur, A., Murray, J.C., Wilcox, A.J. Maternal Alcohol Consumption, Alcohol Metabolism Genes, and the Risk of Oral Clefts. A Population-based Case-Control Study in Norway. Am J Epidomiol. 172:024-31, (2010).

Clugston, R.D., Blaner, W.S. The adverse effects of alcohol on vitamin A metabolism (review). Nutrients 4p:356-371, 2012)

Crocker, N., Vaurio, L., Riley, E.P., Mattson, S.N. Comparison of verbal learning and memory in children with neavy prenatal alcohol exposure or attentiondeficit/hyperactivity disorder. Alcohol clim Exp Res. 35(6).p:1114-1121, (2011).

Dasgupta, A. The Science of Drinking: How Alcohol Affects Your Body and Mind. Lanham Bowman \& Littlefield, 2011. 
Diez-Ruiz, A., Garcia-Gaura, P.L., Garcia-Ruiz, P., Gonzales-Calvin, J.L., Gallego-Rojo, F., Fuchs, D. Alcohol and alcoholism. 45(5) 427-430.

Kim, Y.N., Driskel J.A. vitamins. In: driskell J.A., Wollnsky, I (eds). Nutritional Concerms in Recreation, Exercise, and Sport. New York: CRC.p:91-121, (2009).

Lieberman, M., Marks, A.D., Smith, C. Mark's . Essentials of Medical Biochemistry: A Clinical Approach 2nd ed. Lippincott Williams and Wilkins.p:342-359, (2007).

National Collaborating Centre for Mental Health. Alcohol-Use Disorders: The NICE Guideline on Diagnosis, Assesments, and Management of Harmtul Drinking and Alcohol Dependence. London: The British Psychological Society and The Royal College of Psychiantrists.p:17-27, (2011).

National Institute on Alcohol Abuse and Alcoholism. Alcohol Health \& Research World: Alcohol's Effect on Organ Function. National Technical Information Service. 21 no.1 (1997).

Panjaitan, R.G.P. Bahaya Gagal Hamil yang Diakibatkan Minuman Beralkohol. Disertasi Bogor: Institut Pertanian, 2003.

Wardlaw, GM., Smith, A.M., Lindeman, A.K. Contemporary Nutrition A Functional Approach. McGraw-Hill. p:672-677, (2012).

World Health Organization. Global Status Report on Alcohol and Health. Switzerland: WHO Press, 2011.

Wyper, K.R., Rasmussen, C.R. languange Impairments in children with fetal alcohol spectrum disorder. J Popul Ther Clin Pharmacol 18(2).p:364-376, (2011). 